\title{
MENANAMKAN JIWA KEWIRAUSAHAAN SEJAK USIA DINI DI ERA MEA
}

\author{
Felisitas Ndeot \\ Pendidikan Guru PAUD STKIP Santu Paulus Ruteng \\ Email: ica_asano@yahoo.co.id
}

\begin{abstract}
Abstrak: Tulisan ini dimaksudkan untuk menjelaskan bagaimana cara menanamkan jiwa kewirausahaan pada anak usia dini di era Masyarakat Ekonomi ASEAN (MEA). Penelitianpenelitian yang dilakukan pada anak usia dini menunjukkan pentingnya mengembangkan dan mengenalkan berbagai hal sejak usia dini termasuk kewirausahaan agar di usia selanjutnya jiwa kewirausahaan yang sudah ditanam sejak usia dini berkembang dengan baik dan melahirkan pencipta lapangan-lapangan kerja di masa depan yang mandiri, kreatif, berjiwa pemimpin, dan pekerja keras.
\end{abstract}

Kata kunci: Jiwa Kewirausahaan, Anak Usia Dini, Masyarakat Ekonomi ASEAN

\section{PENDAHULUAN}

Dalam menghadapi MEA sejak tahun 2015, terlihat bahwa Indonesia masih berusaha untuk mengurangi angka pengangguran walaupun data yang dimiliki Badan Pusat Statistik (BPS) bahwa jumlah pengangguran di Indonesia pada Agustus tahun 2017 malah naik menjadi 7,04 juta orang atau terdapat penambahan 10.000 orang dari 7,03 juta orang pada Agustus 2016 yang disebabkan oleh peningkatan jumlah angkatan kerja di Indonesia (Diungkapkan Suhariyanto, Kecuk Kepala Badan Pusat Statistik dalam Kompas. Com). Saat ini pemerintah masih berupaya untuk mengurangi angka pengangguran dengan menyiapkan berbagai lapangan kerja.

\begin{abstract}
Lapangan kerja yang disiapkan pemerintah belum sepenuhnya mampu menyerap tenaga kerja sehingga pemerintah berharap pihak-pihak swasta yang memiliki tujuan memajukan negara dapat menciptakan lapangan kerja yang menyerap lebih banyak tenaga kerja. Semakin banyak pengusaha yang membuka usaha maka kebutuhan akan tenaga kerja semakin meningkat. Oleh karena itu, jiwa kewirausahaan harus dipupuk sejak usia dini untuk menyiapkan generasi muda yang bukan hanya mampu bekerja tetapi mampu menyiapkan lapangan kerja sehingga dapat bersaing di era MEA saat ini.
\end{abstract}




\section{PEMBAHASAN}

\section{Masyarakat Ekonomi ASEAN}

Masyarakat Ekonomi

ASEAN (MEA) dibentuk dengan empat kerangka strategis yakni kawasan ekonomi yang berdaya saing, pertumbuhan ekonomi yang merata, terintegrasi dengan perekonomian global, serta pencapaian pasar tunggal dan kesatuan basis produksi. Kawasan ekonomi yang berdaya saing menuntut masyarakat di ASEAN agar kompetitif dengan memanfaatkan sumber daya manusia yang tinggi dan tenaga kerja yang terampil dan profesional. Pertumbuhan ekonomi yang merata dapat diwujudkan dengan tidak ada lagi kesenjangan ekonomi dan pembangunan di ASEAN. Melalui pasar tunggal dan kesatuan basis produksi, maka masyarakat ASEAN memiliki satu pasar bersama sehingga modal, barang, jasa, dan manusia bebas masuk dan keluar di kawasan ASEAN. Masyarakat di kawasan ASEAN akan mampu bersaing dengan pasar internasional karena sudah terintegrasi dengan perekonomian global melalui pasar tunggal yang menggabungkan barang-barang unggulan dalam satu wadah lalu dipasarkan secara global.

Berdasarkan penjelasan di atas, maka diharapkan di era MEA saat ini, masyarakat ASEAN dan Indonesia pada khususnya mampu mengambil bagian dalam kegiatan perdagangan di pasar tunggal ASEAN dan global. Keterlibatan masyarakat Indonesia dalam pasar tunggal dan global tersebut harus disertai dengan kesiapan sumber daya manusia melalui pendidikan. Kualitas pendidikan ditingkatkan melalui peningkatan kompetensi pendidik seperti kompetensi pedagogik, personal, sosial, dan profesional. Peningkatan kompetensi guru yang meningkat akan memengaruhi kualitas peserta didik sejak usia dini hingga perguruan tinggi.

Pendidikan anak usia dini merupakan acuan bagi pendidikan selanjutnya. Apabila stimulasistimulasi yang diberikan pada usia 
dini sangat bagus maka pada jenjang pendidikan berikutnya peserta didik akan berkembang dengan sangat baik begitu pula dalam hal kewirausahaan. Hasil dari penelitian The National Child Development Study (NCDS) bahwa sebagian besar pengusaha muda yang berada di usia 33 tahun merupakan hasil dari penanaman nilai-nilai kewirausahaan sejak usia dini (Jones \& Jayawarna: 2011). Oleh karena itu, penanaman jiwa kewirausahaan hendaknya dilakukan sedini mungkin untuk menghasilkan wirausahawan handal di kemudian hari.

\section{Jiwa Kewirausahaan}

Kata kewirausahaan diambil dari istilah "Enterpreunership". Menurut Meredith dkk (1996: 9) jiwa enterpreunership adalah semangat, sikap, dan kemampuan individu dalam menangani usaha dan atau kegiatan yang mengarah pada mencari, menciptakan, menerapkan cara kerja baru, teknologi baru, produk baru, atau memberi nilai tambah pada barang dan jasa (Saputra \& Susena, 2013: 43). Seseorang yang memiliki jiwa kewirausahaan di era MEA diharapkan mampu menciptakan lapangan kerja yang baru agar menyerap tenaga kerja lebih banyak. Sejak usia dini jiwa kewirausahaan ditanamkan melalui pengenalan kewirausahaaan dengan bermain seraya belajar. Penanaman jiwa kewirausahaan sejak usia dini akan memengaruhi pandangan anak tentang dunia kewirausahaan di usia selanjutnya. Sedangkan menurut Herawati, kewirausahaan berarti sekumpulan sifat-sifat atau watak yang dimiliki oleh individu yang menunjukkan besarnya potensi untuk menjadi wirausahawan (Saputra \& Susena, 2013: 42-43). Sifat-sifat atau watak tersebut yang harus dipupuk sejak usia dini misalnya mandiri, berjiwa pemimpin, kreatif, dan pekerja keras. Pada era MEA sekarang, seseorang dituntut agar tidak hanya memiliki hard skill tetapi juga soft skill. Hard skill merupakan kemampuan yang diperoleh karena mengikuti pendidikan tertentu dan dipelajari dengan kurun waktu yang sudah ditetapkan agar memiliki profesi tertentu. Soft skill merupakan kemampuan untuk mengelola kecerdasan emosional yang dicirikan dengan kemampuan seseorang untuk berinteraksi dengan orang lain. Salah 
satu bentuk soft skill adalah entreprenurial skill yaitu keahlian untuk menjalankan sebuah usaha. Entreprenurial skill inilah yang harus ditanamkan jiwanya sejak usia dini agar selain memiliki kemampuan akademis yang menunjang profesi, anak juga memiliki jiwa kewirausahaan yang mampu menciptakan lapangan kerja baru di masa depan.

\section{Berdasarkan beberapa}

pendapat di atas, kewirausahaan merupakan proses pengerjaan sesuatu yang baru dan berbeda melalui pengembangan ide dengan memanfaatkan sumber daya yang ada dengan mengedepankan kemandirian, kepemimpinan, kreativitas, dan kerja keras.

\section{Menanamkan Jiwa}

Kewirausahaan Sejak Usia Dini di Era MEA

Pengembangan pendidikan kewirausahaan dalam mengembangkan nilai-nilai kewirausahaan pada anak usia dini dalam pelaksanaannya diintegrasikan sesuai tema dan kegiatan di sekolah. Implementasi dari nilai-nilai pokok kewirausahaan yang dikembangkan pada jenjang pendidikan anak usia dini yaitu: mandiri, kreatif, kepemimpinan, dan kerja keras. Anak dibimbing agar mampu melakukan sendiri segala hal tanpa bantuan orang lain. Kemandirian yang dimiliki anak membantu anak bertanggung jawab terhadap dirinya sendiri termasuk keputusan yang diambilnya dalam melakukan sesuatu atau memecahkan masalah, terutama dalam hal mengimplementasikan kreativitas yang orisinil bukan meniru secara keseluruhan hasil kreativitas orang lain.

Kreativitas tidak hanya mencakup tentang bagaimana seseorang dapat membuat sesuatu yang baru, tapi mencakup seluruh proses dan dimensi yang terkait dalam kreativitas itu sendiri. Beberapa ahli mengemukakan bahwa kreativitas adalah kemampuan seseorang dalam proses berpikirnya untuk menghasilkan sesuatu yang baru. Sebuah proses berpikir dapat berupa ide atau gagasan unik yang tidak terfikirkan sebelumnya. Gagasan atau ide tersebut dapat diterapkan untuk menyelesaikan suatu masalah. Anak yang kreatif memiliki imajinasi yang tinggi, 
mampu berpikir secara divergen, mempunyai rasa ingin tahu yang tinggi dan tidak pantang menyerah. Kreativitas memiliki 4 dimensi yaitu: pribadi, proses, dukungan, dan produk (Isbell \& Raines, 2007: 4). Sebagian orang memercayai bahwa hanya orang tertentu saja yang dianugerahi kreativitas dan memiliki pengaruh yang luar biasa bagi dunia global, seperti Thomas Alva Edison yang menemukan lampu pijar. Orang yang kreatif biasanya membuat sesuatu yang baru yang belum pernah dibuat oleh orang lain sebelumnya atau menciptakan sesuatu yang berbeda. Pada saat menciptakan sesuatu, seseorang akan melewati sebuah proses untuk berkreasi. Pada saat seseorang mengeksplorasi sesuatu menggunakan teknik tertentu, melakukan eksperimen, dan menggunakan cara-cara tertentu yang baru atau berbeda dari orang lain maka orang tersebut telah berkreasi melalui proses yang kreatif. Salah satu cara untuk menjelaskan tentang proses yang kreatif adalah melalui model Creative Problem-Solving (CPS) yang dicetuskan oleh Osbon \& Parnes (1967) dimana untuk memecahkan masalah, anak dibiarkan untuk berpikir divergen. Anak dibiarkan untuk memperoleh jawaban yang benar melalui berbagai ide, melihat jawaban untuk sebuah masalah dari banyak sisi. Agar kreativitas anak berkembang dengan baik maka guru perlu memberikan dukungan, baik lewat penyediaan fasilitas dan lingkungan yang mendukung kreativitas anak maupun dengan penghargaan berupa pujian terhadap hasil kreativitas anak. Hasil kreativitas anak berupa produk kreatif merupakan hasil akhir dari kreativitas yang baru/orisinil maupun hasil penggabungan/elaborasi dari ide lain. Selain kreatif, seorang wirausahawan harus berjiwa pemimpin dan pekerja keras.

Pemimpin merupakan seseorang yang menjadi panutan bagi orang yang dipimpinnya, suka berkomunikasi untuk mengungkapkan idenya kepada orang lain, dan membantu orang lain agar dapat melaksanakan sesuatu sesuai dengan tujuan yang hendak dicapainya bersama-sama. Seorang pemimpin diharapkan memiliki kondisi sosial emosional yang baik agar dapat bekerja sama dengan 
orang lain. Pemimpin merupakan orang yang suka bekerja keras untuk mencapai kesuksesan. Karakteristikkarakteristik inilah yang diharapkan juga dimiliki oleh anak sejak usia dini sebagai calon wirausahawan di masa mendatang. Wirausahawan harus mempunyai kemampuan menemukan dan mengevaluasi peluang-peluang, mengumpulkan semua sumber daya yang dibutuhkan dan melakukan sesuatu agar mendapatkan keuntungan dari peluang-peluang tersebut. Wirausahawan merupakan seorang pemimpin yang berani mengambil resiko, percaya diri, dan berorientasi ke masa depan.

Masa depan yang akan dihadapi anak usia dini saat ini adalah masa depan yang dianugerahi bonus demografi, sehingga bonus demografi akan menjadi anugerah atau bencana pada saatnya nanti tergantung dari kesiapan generasi bangsa Indonesia menghadapinya. Peningkatan kualitas generasi yang dihasilkan sejak usia dini merupakan salah satu faktor keberhasilan menghadapi MEA dan menjalani bonus demografi yang penuh anugerah bukan bencana. Daerah
Nusa Tenggara Timur dan Maluku merupakan daerah yang tidak terkena dampak bonus demografi karena menurut data (Bappenas dkk : 2013) rasio ketrgantungan masyarakat terhadap pemerintah masih sangat tinggi yaitu di atas 50\%. Sejak saat ini masyarakat Nusa Tenggara Timur dan Maluku harus lebih meningkatkan kualitas sumber daya manusia agar mampu memanfaatkan sumber daya alam yang ada dan membuka lapangan kerja yang baru sehingga menyerap banyak tenaga kerja untuk mengejar bonus demografi sehingga walaupun pada awalnya sudah diprediksi tidak memperoleh bonus demografi, masyarakat NTT dan Maluku mampu mengejar ketertinggalan dengan mengurangi angka ketergantungan kepada pemerintah dan memperoleh bonus demografi pada tahun 2045 .

Agar nilai-nilai kewirausahaan berkembang pada anak maka sesuai dengan pendapat John Dewey, bahwa kehidupan sehari-hari harus menjadi sumber aktivitas dimana anak-anak dapat belajar tentang kehidupan dan keterampilan dalam hidup (Morrison, George S., 2012: 68), pendidik perlu 
menyiapkan kegiatan main yang mampu merangsang jiwa kewirausahaan pada anak, anak-anak sejak dini dikenalkan dengan dunia wirausaha. Menanamkan jiwa kewirausahaan dalam pendidikan anak usia dini dapat dilakukan melalui metode proyek. Penerapan metode proyek misalnya dengan melakukan kegiatan menanam tanaman, membuat clay, membuat boneka, dan mengolah bahan pangan lokal. Penerapan metode proyek membantu anak mengatur diri sendiri untuk bekerja sama dengan teman dalam memecahkan suatu masalah, anak mampu mengembangkan kreativitas dalam menghasilkan sebuah produk, bekerja keras menyelesaikan proyek yang dibuat, bertanggung jawab, mampu memimpin teman-teman dalam kelompok, dan menyelesaikan tugas tepat pada waktunya. Hasil dari proyek yang dilaksanakan dipamerkan, disajikan, dan dipasarkan. Pelaksananaan metode proyek dimulai dengan menentukan tema kegiatan, merumuskan tujuan, menentukan jadwal kegiatan, melakukan pembagian tugas, menyiapkan bahan dan peralatan, melaksanakan kegiatan, dan mengkomunikasikan hasil proyek. Jiwa kewirausahaan juga dapat dikembangkan pada anak usia dini melalui bermain pasar-pasaran. Anak diajak untuk bermain menjadi penjual dan pembeli.

\section{KESIMPULAN}

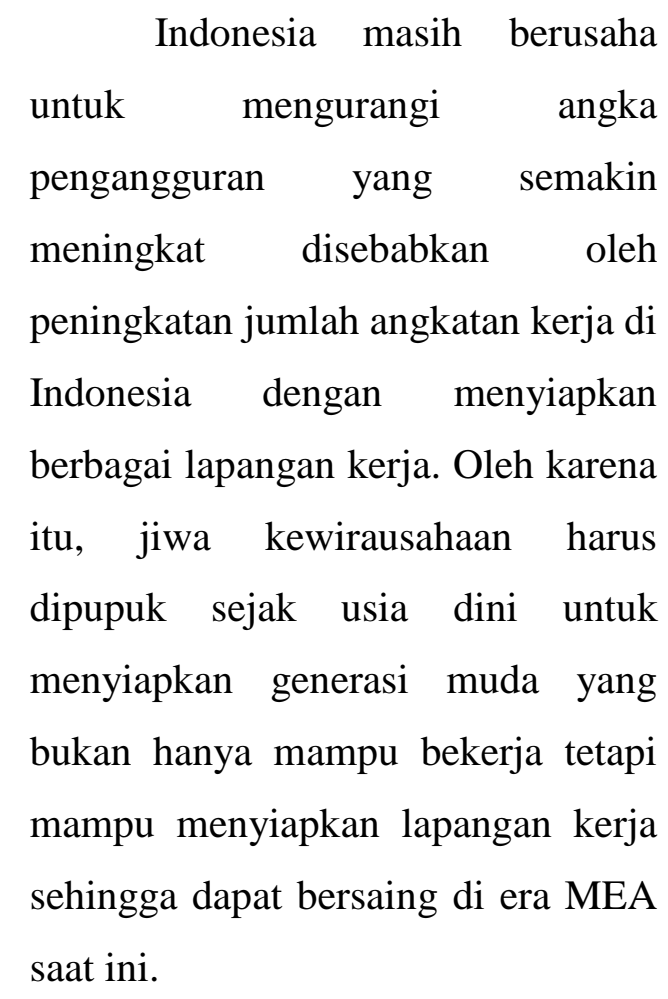

Masyarakat

Ekonomi

ASEAN (MEA) dibentuk dengan empat kerangka strategis yakni kawasan ekonomi yang berdaya saing, pertumbuhan ekonomi yang merata, terintegrasi dengan perekonomian global, pencapaian pasar tunggal dan kesatuan basis produksi. Di era MEA saat ini, 
masyarakat ASEAN dan Indonesia pada khususnya diharapkan mampu mengambil bagian dalam kegiatan perdagangan di pasar tunggal ASEAN dan global. Keterlibatan masyarakat Indonesia dalam pasar tunggal dan global tersebut harus disertai dengan kesiapan sumber daya manusia melalui pendidikan.

Pendidikan anak usia dini merupakan acuan bagi pendidikan selanjutnya. Apabila stimulasistimulasi yang diberikan pada usia dini sangat bagus maka pada jenjang pendidikan berikutnya peserta didik akan berkembang dengan sangat baik begitu pula dalam hal kewirausahaan. Sejak usia dini jiwa kewirausahaan ditanamkan melalui pengenalan kewirausahaaan dengan bermain seraya belajar. Kewirausahaan merupakan proses pengerjaan sesuatu yang baru dan berbeda melalui pengembangan ide dengan memanfaatkan sumber daya yang ada dengan mengedepankan kemandirian, kepemimpinan, kreativitas, dan bekerja keras.

Pelaksanaan pengembangan nilai-nilai kewirausahaan di TK diintegrasikan sesuai tema dan kegiatan di sekolah. Implementasi dari nilai-nilai pokok kewirausahaan yang dikembangkan pada jenjang pendidikan anak usia dini yaitu: mandiri, kreatif, kepemimpinan, dan kerja keras. Nilai-nilai tersebut harus juga dimiliki oleh masyarakat Nusa tenggara Timur sejak usia dini. Masyarakat Nusa Tenggara Timur dan Maluku harus lebih meningkatkan kualitas sumber daya manusia agar mampu memanfaatkan sumber daya alam yang ada dan membuka lapangan kerja yang baru sehingga menyerap banyak tenaga kerja untuk mengejar bonus demografi sehingga walaupun pada awalnya sudah diprediksi tidak memperoleh bous demografi, masyarakat NTT dan Maluku mampu mengejar ketertinggalan dengan mengurangi angka ketergantungan kepada pemerintah dan memperoleh bonus demografi pada tahun 2045 .

Pengenalan kewirausahaan dan penanaman jiwa kewirausahaan pada anak usia dini dapat dilakukan melalui penerapan metode proyek dan bermain pasar-pasaran. Melalui kegiatan-kegiatan tersebut, diharapkan anak mampu memiliki jiwa kewirausahaan dan menjadi 
pengusaha di masa depan yang dapat membuka lapangan kerja baru dan mampu bersaing menghadapi MEA serta memperoleh anugerah bonus demografi.

\section{DAFTAR PUSTAKA}

Bappenas dkk. (2013). Proyeksi Penduduk 2010 - 2035.

Http://ekonomi.kompas.com/read/20 17/11/06/153940126/agustus2017-jumlah-penganggurannaik-menjadi-704-juta-orang.

Isbell, Rebecca T., \& Shirley C. Raines. (2007). Creativity and the Arts with Young Children (Second edition). Delmar Engage Learning : Canada.

Jones, Ossie \& Jayawarna Dilani. (2011). Entrepreneurial Potential: the Role of Human Capital. Institute for Small Bussiness and entrepreneuship: United Kingdom.

Morrison, George S. (2012). Dasardasar Pendidikan Anak Usia
Dini (terjemahan). PT Indeks: Jakarta.

Saputra, Ari Dian \& Susena. (2013). Kontribusi Mata Kuliah Kewirausahaan dalam Menumbuhkan Jiwa Enterpreunership yang Beretika pada Mahasiswa Prodi PPKn FKIP UAD Yogyakarta. Jurnal Citizenship, Vol. 2 No. 1. 